\title{
Regarding Politics
}





\title{
Regarding Politics Essays on Political Theory, Stability, and Change
}

\author{
Harry Eckstein
}


University of California Press

Berkeley and Los Angeles, California

University of California Press, Ltd.

Oxford, England

Copyright @ 1992 by

The Regents of the University of California

\section{Library of Congress Cataloging-in-Publication Data}

Eckstein, Harry.

Regarding politics: essays on political theory, stability, and change / Harry Eckstein.

p. $\quad \mathbf{c m}$.

Includes bibliographical references and index.

ISBN 0-520-07167-0 (cloth). - ISBN 0-520-07722-9 (paper)

1. Political science. 2. Political stability. 3. Political development. I. Title.

JA38.E24 1992

91-18245

$320-\mathrm{dc} 20$

CIP

Printed in the United States of America

123456789

The paper used in this publication meets the minimum requirements of American

National Standard for Information Sciences-Permanence of Paper for Printed Library Materials, ANSI Z39.48-1984 () 
For Silvia

with love and gratitude 
